\title{
Determination of alkaloids and oil rates of some poppy (papaver somniferum L.) varieties cultivated as winter and summer
}

\author{
Levent YAZICI *1, Güngör YILMAZ²
}

${ }^{1}$ Directorate of Middle Black Sea Transition Zone Agricultural Research Institute, Tokat, Turkey

${ }^{2}$ Department of Field Crops, Faculty of Agriculture, Gaziosmanpaşa University, Tokat, Turkey

Received: 05 May 2017 - Revised: 12 September2017 - Accepted: 03 October 2017

\begin{abstract}
The aim of this study is to determine the alkaloid and oil rates contents of some poppy (Papaver somniferum L.) varieties, such as morphine, codeine, oripavine, thebaine, noscapine and papaverine, which are planted as winter and summer. Five varieties of poppy (Zaferyolu, TMO 2, Ofis NP, Ofis 4, Anayurt) registered in different organizations were used in the research. The study was carried out in the trial field belonging to Tokat Middle Black Sea Crossing Belt Agricultural Research Institute Directorate in 2015 and 2016. Alkaloid analyzes were carried out on an HPLC device in the Bolvadin Alkaloid Plant Laboratory. The study was carried out in three replications according to randomized block trial design. As a result; Varieties of poppy the cultivated as summer, mean morphine value $0.61-1.19 \%$, the codeine $0.07-0.25 \%$, the oripavine $0.01-0.02 \%$, thebaine $0.02-0,11 \%$, noscapine, $0,04-0,49 \%$, papaverine , 0,03-0,18 and oil ratio values varied between 41,6-48,8 \%. Varieties of poppy the cultivated as winter; mean morphine value $0.29-0.56 \%$, the codeine $0.04-0.09 \%$, the oripavine $0.0002-0.007$ $\%$, thebaine $0.01-0.06 \%$, noscapine, 0.009-0.93\%, papaverine , 0.00-0.06\%, and oil ratio values varied between 45.3-54.3\%. Poppy varieties cultivated as summer, according to winter sown alkaloid ratios are higher and oil ratios are lower.
\end{abstract}

Keywords: Poppy, Papaver somniferum L., alkaloid, oil, winter, summer

\section{INTRODUCTION}

Poppy (Papaver somniferum L.), which human beings have used as natural painkillers since ancient times, is a medical industry plant that is now widely used by the pharmaceutical industry. The major alkaloids such as morphine, codeine, oripavine, tebain, papaverine, and noscapine are obtained from the opium poppy capsule from which a large number of important alkaloids are obtained. It is grown in Turkey, India, Australia, Spain, France and Hungary as legal main producer countries under the supervision of the United Nations to obtain opium and opium alkaloids for medicinal purposes in World. India produces opium gum, whereas other countries produce dried opium capsules.

The average legal opium poppy cultivation area in 2011-2016 is 103.893 ha on the basis of main producers in the world. The average cultivation area in Turkey in 2011-2016 is 43.151

\footnotetext{
*Corresponding Author E-mail: leventyzc@gmail.com
} 
ha, which accounts for $41.5 \%$ share of total legal opium poppy cultivation areas in the world. The average capsule production of the main producer countries of the world in 2010-2014 was 63.856 tons. Turkey had a $35 \%$ share among legal capsule producers with 22.699 tons of average capsule production in 2010-2014 [1].

Papaver somniferum L. the opium poppy, is a traditionally cultivated annual cultivar. It is from papaveraceae family of Rhoedales group. It is classified in Papaver genus of this family. There are 28 kinds and 18 kinds of taxa were detected in papaveraceae family of our country [2].

Opium poppy farming in Turkey is implemented within the 70 thousand hectares limit allocated by the United Nations Organization for our country in areas permitted by the Council of Ministers and within the planning framework of General Directorate of Turkish Grain Board. The production is subject to licensing and control in the form of dried opium poppy capsules without incision. The cultivation in 2016/2017 winter and summer farming season took place in Afyonkarahisar, Denizli, Konya, Burdur, Uşak, Isparta, Eskişehir, Kütahya, Manisa, Balıkesir, Çorum, Amasya and Tokat provinces [3].

Poppy is generally planted in winter, but can also be planted in summer when the winter is harsh or when it is very hard in winter. The time of sowing is the first week of October, though it varies according to the region. The sowing time in summer term is the end of March and the beginning of April.

\section{MATERIAL and METHODS}

This experimental study was conducted in the trial field of Central Black Sea Gateway Zone Agricultural Research Institute in vegetation periods 2015 and 2016. In the study, 5 opium poppy varieties (Zaferyolu, TMO 2, Ofis NP, Ofis 4, Anayurt) registered in different organizations were used as material. Each variety was planted in two rows $3 \mathrm{~m}$ in length according to randomized blocks experimental design. Row spacing was set to $40 \mathrm{~cm}$ and plant spacing was set to $10 \mathrm{~cm}$ later by thinning. The summer planting was implemented on 27 February, 2015, winter planting was implemented on16.10.2015. Plant care such as fertilization, thinning, irrigation, and hoeing works was conducted and diseases and pests were fought when necessary during the vegetal development of opium poppy plant. 20-20-0 Compound NP fertilizer was applied as $6 \mathrm{~kg} / \mathrm{da} \mathrm{N}$ during sowing and AN (ammonium nitrate) fertilizer was administered as $6 \mathrm{~kg} / \mathrm{da} \mathrm{N}$ before the first hoeing. Upon the maturation of all capsules in the trial field, they were harvested by picking up by hand on $30 \mathrm{July}, 2015$ in summer plantations and in winter on October 15, 2016.

\section{RESULTS and DISCUSSIONS}

Statistical analyzes including the mean values of alkaloid (morphine, codeine, oripavine, thebaine, nosapine and papaverine) and oil proportions of the varieties used in the experiment are given in Table 1. As is seen from Table 1, it has been found out that the average morphine ratio values of the poppy cultivars grown in summer and winter are statistically significant when compared. The morphine content of summer varieties ranged from $0.62 \%$ to $1.11 \%$ and the morphine content of winter poppy cultivars ranged from $0.29 \%$ to $0.56 \%$. The highest morphine ratio among the cultivated varieties was in the Ofis NP variety during both summer and winter. In the previous studies, Inan (2013), a study on opium poppy to determine the important agronomic characteristics and amount of oil and morphine in poppy (Papaver somniferum L.) in 2012-2013. It reported that crude oil ratio $49.05 \%-51.32 \%$, and morphine ratio $0.56 \%-0.92 \%$ [4]. Erdurmus (1989), morphine proportions were found $0.32-0.82 \%$ [5], Novak and Strakova (1989), $0.66-0.75 \%$ in 20 opium poppy varieties [6] and Arslan 
(2000), $0.25-0.89 \%$ in 353 samples collected from various regions [7]. The results obtained from our study exhibit great similarities to the findings from these studies.

Table 1. Mean values and statistical analyzes concerning alkaloids and oil proportions of varieties.

\begin{tabular}{|c|c|c|c|c|c|c|c|c|}
\hline $\begin{array}{l}\text { Sowing } \\
\text { time }\end{array}$ & Variety & $\begin{array}{l}\text { Morphine } \\
\text { rations (\%) }\end{array}$ & $\begin{array}{c}\text { Codeinerations } \\
(\%)\end{array}$ & $\begin{array}{c}\text { Oripavine } \\
\text { rations } \\
(\%)\end{array}$ & $\begin{array}{c}\text { Thebaine } \\
\text { rations } \\
(\%)\end{array}$ & $\begin{array}{l}\text { Papaverine } \\
\text { rations (\%) }\end{array}$ & $\begin{array}{c}\text { Noscapine } \\
\text { rations } \\
(\%)\end{array}$ & $\begin{array}{c}\text { Oil } \\
\text { rations } \\
(\%)\end{array}$ \\
\hline Summer & Anayurt & 0,72 & 0,18 & 0,03 & 0,09 & 0,18 & 0,09 & 44,5 \\
\hline Summer & Ofis 4 & 1,19 & 0,25 & 0,01 & 0,08 & 0,11 & 0,08 & 43,1 \\
\hline Summer & Ofis NP & 1,11 & 0,13 & 0,03 & 0,08 & 0,07 & 0,50 & 41,6 \\
\hline Summer & TMO 2 & 0,62 & 0,07 & 0,02 & 0,03 & 0,03 & 0,07 & 48,8 \\
\hline Summer & Zaferyolu & 0,90 & 0,26 & 0,02 & 0,11 & 0,06 & 0,05 & 44,1 \\
\hline Winter & Anayurt & 0,29 & 0,07 & 0,00 & 0,05 & 0,04 & 0,04 & 45,3 \\
\hline Winter & Ofis 4 & 0,51 & 0,10 & 0,00 & 0,06 & 0,07 & 0,05 & 45,6 \\
\hline Winter & Ofis NP & 0,56 & 0,07 & 0,00 & 0,01 & 0,00 & 0,94 & 48,6 \\
\hline Winter & TMO 2 & 0,52 & 0,05 & 0,01 & 0,07 & 0,00 & 0,00 & 51,0 \\
\hline Winter & Zaferyolu & 0,31 & 0,04 & 0,00 & 0,05 & 0,01 & 0,01 & 54,3 \\
\hline \multicolumn{2}{|c|}{$\begin{array}{l}\text { Average of summer } \\
\text { planting }\end{array}$} & 0,90 & 0,17 & 0,021 & 0,07 & 0,09 & 0,15 & 44,4 \\
\hline \multicolumn{2}{|c|}{$\begin{array}{l}\text { Average of winter } \\
\text { planting }\end{array}$} & 0,43 & 0,06 & 0,002 & 0,04 & 0,02 & 0,20 & 49,0 \\
\hline \multicolumn{2}{|c|}{ Squares average } & 0,55 & 0,03 & 0,00 & 0,00 & 0,01 & 0,006 & 51,3 \\
\hline \multicolumn{2}{|c|}{ F Value } & $14,50 *$ & $9,48^{*}$ & $38,29 *$ & 3,77 & $5,11^{*}$ & 0,06 & 4,79 \\
\hline \multicolumn{2}{|c|}{$\mathrm{CV}(\%)$} & 28,93 & 47,13 & 39,02 & 41,93 & 78,94 & 174,7 & 6,99 \\
\hline
\end{tabular}

Statistical significance was found when the average codeine ratio values of poppy cultivars grown in summer and winter were compared. The codeine ratio of cottage varieties varied between $0.07 \%-0.26 \%$ for summer grown poppy and the codeine varieties of winter grown poppy varieties varied between $0.04 \%-0.10 \%$. The average value of varieties in summer sowing was $0.17 \%$, while the average value in winter varieties was $0.06 \%$. The highest rate of codeine in summer varieties was found in Zaferyolu variety and the highest rate of codeine in winter varieties was found in Ofis 4 variety. Statistical significance was found when the average oripavine ratio values of the varieties were compared. The oripavine ratio value of summer varieties varied between $0.01 \%-0.03 \%$ and the oripavine value range of winter poppy varieties varied between $0.00-0.01 \%$. The average value of varieties in summer sowing was $0.02 \%$ while the average value in winter varieties was $0.002 \%$.

Statistically significant difference was not found when the average tebaine ratio values of the varieties were compared. The tebaine ratio value of the summer varieties varied between $0.03-0.11 \%$, and the tebaine value range of winter poppy varieties varied between $0.01-0.03$ $\%$. The average value of varieties in summer sowing was $0.07 \%$ while the average value in winter varieties was $0.04 \%$. The highest tebaine ratio in winter varieties was found in Zaferyolu variety and the highest tebaine ratio in winter varieties was found in TMO 2 variety.

Statistically significant difference was found when the average papaverine ratio values of the varieties were compared. The values of papaverine ratio of summer varieties ranged between $0,03-0,18 \%$ and that of winter poppy varieties varied between $0,00-0,07 \%$. The average value of varieties in summer sowing was $0.09 \%$, while the average value in winter varieties was $0.02 \%$. The highest proportion of papaverine in summer varieties was found in the Anayurt variety and the highest papaverine ratio in winter varieties was found in the Ofis 4 variety. 
Statistically significant difference was not found when the average noscapine ratio values of the cultivars were compared. The noscapine ratio value of summer varieties ranged from $0,03-0,11 \%$ and the noscapine value of winter poppy variety ranged between $0,01-0,03 \%$. The average value of varieties in summer sowing was $0.07 \%$ while the average value in winter varieties was $0.04 \%$. The highest noscapine ratio in winter varieties was found in Zaferyolu variety and the highest noscapine ratio in winter varieties was found in TMO 2 variety.

Statistically significant difference was not found when the average oil values of the varieties were compared. The oil content of the summer varieties ranged from 41 to $48 \%$ and the oil content of the poppy cultivars varied from 45 to $54 \%$. The average value of varieties in summer cultivation was $44 \%$ while the average value in winter varieties was $49 \%$. The highest oil content in summer varieties was found in the TMO 2 variety and the highest oil content in winter varieties was found in the Zaferyolu variety.

\section{CONCLUSION}

As a result, morphine, codeine, oripavine, tebaine, and papaverine ratios of poppy cultivars grown during summer was higher and in winter periods was lower. Noscapin ratios of poppy cultivars grown during winter was higher and in summer periods was lower. The average morphine value of varieties in summer sowing was $0.90 \%$ while the average value in winter varieties was $0.43 \%$. The average codeine value of varieties in summer sowing was $0.17 \%$ while the average value in winter varieties was $0.06 \%$. The average oripavine value of varieties in summer sowing was $0.02 \%$ while the average value in winter varieties was $0.002 \%$. The average thebaine value of varieties in summer sowing was $0.07 \%$ while the average value in winter varieties was $0.04 \%$. The average papaverin value of varieties in summer sowing was $0.09 \%$ while the average value in winter varieties was $0.02 \%$. The average noscapin value of varieties in summer sowing was $0.15 \%$ while the average value in winter varieties was $0.20 \%$. Oil percentage values were found low in summer sowing and higher in winter sowing. The average oil value of varieties in summer sowing was $44.4 \%$ while the average value in winter varieties was $49.0 \%$.

\section{Conflict of Interests}

Authors declare that there is no conflict of interests.

\section{REFERENCES}

[1]. Anonymous, (2016). INCB Narcotic Drugs Estimated World Requirements for 2016. United Nations Publication, New York.

[2]. Anonymous, (2017). Turkish plants data Service, Web Site: http://www.tubives.com/ Access Date: 25.03.2017

[3]. Anonymous, 2015. 2014 Poppy Sector Report. Turkish Grain Board General Directorate, Ankara

[4]. Inan, S. (2013). Determination of Amount of Oil and Morphine with Some Agricultural Characteristics in Poppy (Papaver Somniferum L.), Graduate Thesis, Field Crops Department, 2013.

[5]. Erdurmuş, A. (1989). In Poppy lines (Papaver somniferum L.) relationships with the morphine and seed yield of phonological and morphological characters. PhD Thesis, Graduate School of Natural and Applied Sciences, Ankara University-Ankara.

[6]. Novak, J., \& Strakova, V. (1989). Evaluation of selected poppy (Papaver somniferum L.) varieties. Rostlinna Vyroba. Vysoka Skola Zemedelska, 16521 Prague, 6- Suchdol, Czechoslovakia.

[7]. Arslan, N., Büyükgöçmen, R., \& Gümüşçü, A. (2000). Oil and Morphine Contents of Turkish Poppy Populations. Field Crops Central Research Institute Journal. (9), 1-2 2000. 